\title{
Woman in agriculture, and climate risks: hotspots for development
}

\author{
Nitya Chanana-Nag ${ }^{1}$ (D) Pramod K. Aggarwal ${ }^{1}$
}

Received: 31 August 2017 / Accepted: 7 June 2018 /Published online: 3 August 2018

(C) The Author(s) 2018

\begin{abstract}
There is rising interest among research and development practitioners to arrive at impact driven solutions in the field of gender and climate change adaptation. Climate change adaptation interventions can be better targeted by being linked with type of climatic risks experienced by women farmers, their social profile and their needs based on the role they play in agriculture. This study presents a methodology to identify hotspots where climate change adaptation and gender based interventions could be prioritized. The methodology is illustrated for India. The results suggest 36 hotspots across 10 states in India, where large number of women farmers are impacted by high levels of drought probability, excess rainfall and heat wave. The target population in these hotspots comprise $14.4 \%$ of the total women farmers in the country. A socioeconomic characterization of the hotspot population highlights barriers, such as labor, credit and market access for female cultivators and lower wage rates for female laborers in these hotspots. Based on the constraints as well as the climatic risks faced by these women in the hotspots, the potential of climate-smart agriculture technologies and practices are emphasized. Additionally, a comparison of current research being done in the field with the results of the study highlights the potential to learn from current efforts for efficient scalability of gender and climate change adaptation interventions.
\end{abstract}

Keywords Climate-smart agriculture Climate change adaptation · Female in agriculture Hotspots

This article is part of a Special Issue on "Gender Responsive Climate Smart Agriculture: Framework, Approaches and Technologies" edited by Sophia Huyer and Samuel Tetteh Partey.

Nitya Chanana-Nag

n.chanana@cgiar.org

1 CGIAR Research program on Climate Change, Agriculture and Food Security, Borlaug Institute for South Asia, International Maize and Wheat Improvement Center, CIMMYT, New Delhi 110012, India 


\section{Introduction}

Emerging literature in the area of climate change adaptation and gender in agriculture has been increasingly highlighting the need to focus on women farmers (Nyasimi and Huyer 2017; Kristjanson et al. 2017). Several studies have engaged in understanding the differences between men and women in terms of their adaptive capacities and vulnerabilities to climate change. These have established that climate change is not gender neutral, and impacts women more adversely than men (Habtezion 2013; Goh 2012). Some studies suggest socioeconomic variables, such as poverty as well as lower access to resources compared to men, as crucial contributing factors for the differences in vulnerabilities and coping capacities of men and women (Mersha and Van Laerhoven 2016; Mehar et al. 2016). Accordingly, other studies highlight that the gender specific roles in agriculture define the differences in impact, and thus the adaptation interventions for both genders (Murage 2015; Khan et al.2016).

Most existing literature on climate change adaptation and gender issues focuses on specific geographical regions, which in major cases is at a micro or local level. For example, studies in Africa highlight gender-related issues in districts that were chosen based primarily on the degree of climate risks involved (Mersha and Van Laerhoven 2016; Mnimbo et al. 2016). Others selected their study villages and households based on criteria, such as presence of research partners or as part of project sites (Pérez et al. 2015; Jost et al. 2015). While the locations of these studies may be relevant from a climate change perspective, it is possible that the proportion of women farmers may not be as considerable, compared to other regions facing similar or higher risks.

A number of studies have highlighted the importance of gender inclusiveness of climate change adaptation interventions, to achieve equitable outcomes (Mittal 2016, Fisher and Carr 2015). In this context, it would be efficacious to inform all agencies about regions, where a large female population is exposed to high degrees of climate risks, and thereby strategize on how best to maximize the impact of their interventions. In the broader field of climate change, several studies have adopted the approach of "hotspot" mapping. For example, climate change vulnerability has been mapped with parameters, such as globalization vulnerability and food insecurity to identify regions facing exposure to both variables on a national and global scale (o'Brien et al. 2004; Ericksen et al. 2011). Similarly, Thornton et al. have mapped climate change vulnerability hotspots for priority setting and targeting of locations for specific interventions (Thornton et al. 2008). In most of these studies, gender is either excluded or incorporated only as part of a broader index comprising of other socioeconomic parameters. Moreover, studies that consider the number of people with other risks do not differentiate between male and female. Thus, gender differentiation is a missing component in these studies. Prioritization of regions as a first step for climate change and gender based interventions, specifically for adaptation, is a research gap that this paper aims to address.

Agriculture employs $60 \%$ of the total female working population in South Asia (ILO 2016). Women cultivators face multiple constraints for production, including those related to social and gender norms and limited resource access, which are further magnified in the wake of climate change (Nyasimi and Huyer 2017). However, not all women dependent on agriculture work on their own lands. A substantial proportion of women also work as agricultural labourers in exchange for a wage payment. In Indian agriculture, for instance, out of the 97.5 million females in the rural sector, $37.3 \%$ work as cultivators and $62.7 \%$ as agricultural laborers. A laborer is exposed to higher financial risks compared to a cultivator, primarily due to seasonality in employment and therefore is threatened by an irregularity in income, which is 
exaggerated in case of adverse climate conditions. In addition, lower wage rates for female laborers compared to males, make them economically more deprived (Srivastava and Srivastava 2017; Subathra 2015). Participation in agriculture in the form of a laborer or cultivator, therefore, can have different intervention implications. In order to further streamline these interventions, it is also important to understand the socioeconomic characteristics that make women in agriculture more vulnerable to climate change impact or lowers their capacity to adapt to climatic stresses. It is known that climate change impact not only intensifies poverty, it also strengthens the existing gender inequalities related to access to resources necessary to cope with climate change (Demetriades and Esplen 2008). The same concept applies to small and marginal farmers, who have a higher susceptibility to climate risks than large farmers. Social class and caste systems, common in countries, such as India, also influence the coping capacity of farmers, especially women, to climate stresses (Ray-Bennett 2009; Sugden and Clement 2014). Additionally, increasing trend of rural male outmigration in South Asia is further challenging the traditional roles of female farmers, by increasing their agricultural as well as domestic responsibilities, thus aggravating their exposure to climate risks (Bhatta et al. 2015).

Adaptation interventions in the form of climate-smart agriculture (CSA) are being increasingly suggested as a means of reducing the impact of climate risks on farmers (World Bank Group, FAO, IFAD 2015). As opposed to traditional agricultural practices mostly aimed at improving productivity or income, CSA practices and technologies can help farmers improve their agricultural productivity, lower their field labor requirements, and provide diverse income options, while building their resilience towards future climate risks (Lipper et al. 2014; World Bank Group, FAO, IFAD 2015). In case of laborers, CSA can assist in improving their subsistence agriculture productivity to reduce their high dependency on wage labor. However, studies have shown that these benefits may not be fully derived unless attention is paid specifically to gender needs and constraints in agriculture, specifically to those of women farmers (Bernier et al. 2015). Therefore, in order for CSA interventions to be equitable and gender responsive, it is imperative that the contribution of women farmers and at the same time the existing gender gap in agriculture is analyzed and taken into account.

The objective of the study, therefore, is to first present a methodology for identification of hotspots for climate risks and women in agriculture; second, to illustrate this for India, a large country with a rich diversity in climate, gender, income and livelihood related issues; and third, to compare the findings with those of other studies. The hotspots can be defined as the regions, where there is maximum concentration of women farmers impacted by high degree of climatic risks. The methodology can be applied as the first level of targeting broad geographical regions for implementing climate change adaptation measures for female farmers. The study also highlights major socioeconomic constraints faced by women farmers in these hotspots. Results of a systematic literature review highlight the results of studies conducted outside of these hotspots.

\section{Method}

The study identifies hotspots for India using two parameters, female participation in agriculture and climate risks. Considering data availability, the study has been conducted at the district level. 


\subsection{Female participation in agriculture}

Female participation in agriculture is defined as the absolute number of females whose major economic activity is working in agriculture as either a cultivator ${ }^{1}$ or a laborer. ${ }^{2}$ This parameter was derived by compiling rural level data on total female cultivators and agriculture laborers (combining main and marginal workers for both) at district level in India. The dataset is for 2011 for 641 districts across 29 states and 7 Union Territories from the population census of India (Census of India 2011). Main and marginal workers are defined by the duration of work done in a year, with the former working for 6 months or more, and the latter for less than 6 months. The aggregation of cultivators and laborers for calculating female participation was done keeping in mind higher focus on the total number of females being impacted by climate risks rather than the duration or type of their involvement in agriculture.

\subsection{Climatic risks}

Three types of climatic risks, drought, extreme rainfall, and heat waves were mapped using gridded data from the Indian Meteorological Department. These three risks have a substantial impact on the production of the major crops (Rao et al. 2015; Singh et al. 2017).

The values of drought were derived using the standardized precipitation index (SPI) data from 1981 to 2011 for the months of June to September, and indicate the probability of occurrence of moderate and severe drought. Extreme rainfall is defined as the average number of days when daily rainfall exceeded $50 \mathrm{~mm}$ during the months of June, July, August, September, and October through 1981-2011. Similarly, heat wave has been defined as the annual average number of days when maximum temperature of a station exceeded the normal maximum temperature of a station by more than or equal to $4-7^{\circ}$ (depending on the region) from March to May during 1981-2011. The grid size of precipitation data used is $0.25^{\circ}(\sim 25 \mathrm{~km})$ and that of temperature is $1^{\circ}(\sim 110 \mathrm{~km})$.

\subsection{Hotspot identification}

The final analysis was done by overlaying female participation with climate risks using a geographic information system (GIS). The gridded data for climatic risks was first converted into district level using zonal statistics feature in the software. Data for the parameters, female participation and climatic risks, was classified into five different categories (Very Low, Low, Medium, High, and Very High) using the Jenk's natural break classification. ${ }^{3}$ The overlay analysis prioritized the intersection of "High" and "Very High" classes for the parameters to highlight the districts, where maximum population of females in agriculture is impacted as a result of the higher degrees of climate risk. These districts were defined as the hotspots, where both the female participation as well as the climate risks belonged to "High" or "Very High" categories. While the population in the other categories (Very Low to Medium) also faces climatic risks, the intensity of the risk as well as the female population in agriculture affected is

\footnotetext{
${ }^{1}$ As per the census of India, a cultivator is a person who engages in cultivation of land and includes effective supervision or direction in cultivation and may also involve ploughing, sowing, harvesting and production of crops. (http://censusindia.gov.in)

2 As per the census of India, a labourer is a person who works on another person's land for wages in money or kind or share, without any risk in the cultivation. (http://censusindia.gov.in)

${ }^{3}$ Jenk's natural breaks method of classification creates classes based on the natural groupings within the data. Class boundaries group as similar values as possible and maximize the differences between the classes.
} 
relatively lower than those in the hotspots. Hence, for the purpose of analysis, these three categories were excluded in the overlay process.

\subsection{Systematic literature review}

A systematic literature review of articles was undertaken to understand if the past studies conducted in India match the hotspots. Only primary studies (journal articles, working paper, reports) in gender, agriculture, and climate change in India were considered. A combination of title (TI) and topic (TO) search in Web of Science was conducted (Table 1) for a 10-year period (2007 July 2017). Search terms were shortened to root form in order to broaden the scope of the results (e.g., "climat*.," rather than "climate" or "climatic"). A keyword search in Google scholar was also conducted to shortlist a comprehensive list of articles. This included using the terms "gender" and "climate change" along with the names of all the states in the country.

\section{Results}

\subsection{Identification of "hotspots"}

Table 2 shows the results of the Jenk's classification. Only "High" or "Very High" classes were considered for hotspots identification.

There are 94.2 million females involved in agriculture in India, across 641 districts with different levels of participation (Census of India 2011). Female farmers in districts with "High" and "Very high" levels of participation comprise $40.3 \%$ of the total female population in agriculture in the country. As depicted by Fig. 1, most of them are concentrated along the western and southern parts of the Deccan plateau including Maharashtra, Andhra Pradesh, and Telangana. A substantial number is also present in some districts of Rajasthan, Bihar, Uttar Pradesh, and Madhya Pradesh.

Female workforce in agriculture is dominated by agricultural laborers. While majority of the female cultivators are present in the western parts of the country, the female laborer's presence is dominant along the eastern rice growing regions of the country from the IndoGangetic plains in Uttar Pradesh and in Bihar in the north to the south eastern districts of Andhra Pradesh and Tamil Nadu in the South.

The country is exposed to multiple climatic risks with varying degrees of impact. Figure 2 highlights the regions facing the highest degree ("High" and "Very High") of three types of climate risks. The northern parts of the country, including the rice-wheat intensive Indo-

Table 1 Search terms used for systematic literature review in Web of Science

\begin{tabular}{ll}
\hline Topic covered & Search terms \\
\hline Climate change & TI $=$ (climat* OR variabili* OR resilien* OR weather* OR shock* OR adapt* \\
& OR flood* OR drought* OR warm* OR heat OR rain) \\
Gender & AND \\
& TI $=$ (gender OR women OR woman OR female OR men OR man OR male \\
& OR young OR youth) \\
India & AND \\
& TO $=$ (India) \\
\hline
\end{tabular}


Table 2 Classification of hotspot parameters, 'female participation in agriculture' and 'climate risks'

\begin{tabular}{llccc}
\hline Classes & $\begin{array}{l}\text { Total females in } \\
\text { agriculture (in '000) }\end{array}$ & $\begin{array}{l}\text { Probability of } \\
\text { drought }\end{array}$ & $\begin{array}{l}\text { Number of heat } \\
\text { wave days }\end{array}$ & $\begin{array}{l}\text { Number of excess } \\
\text { rainfall days }\end{array}$ \\
\hline Very low & $0.01-69.5$ & $0.2-10.0$ & $0-2.4$ & $0.3-2.4$ \\
Low & $69.5-160.7$ & $10.0-16.3$ & $2.4-5.6$ & $2.4-4.4$ \\
Medium & $160.7-280.0$ & $16.3-23.8$ & $5.6-8.4$ & $4.4-8.1$ \\
High & $280.0-445.4$ & $23.8-33.8$ & $8.4-10.8$ & $8.1-15.3$ \\
Very high & $445.4-775.2$ & $33.8-62.1$ & $10.8-13.6$ & $15.3-25.9$ \\
\hline
\end{tabular}

Gangetic plain, experiences the maximum number of heat wave days (11 days) as opposed to the rest of the country ( 3 days). The regions exposed to higher probability of drought, on the other hand, are spread across the country, including parts of central, north east, and arid regions

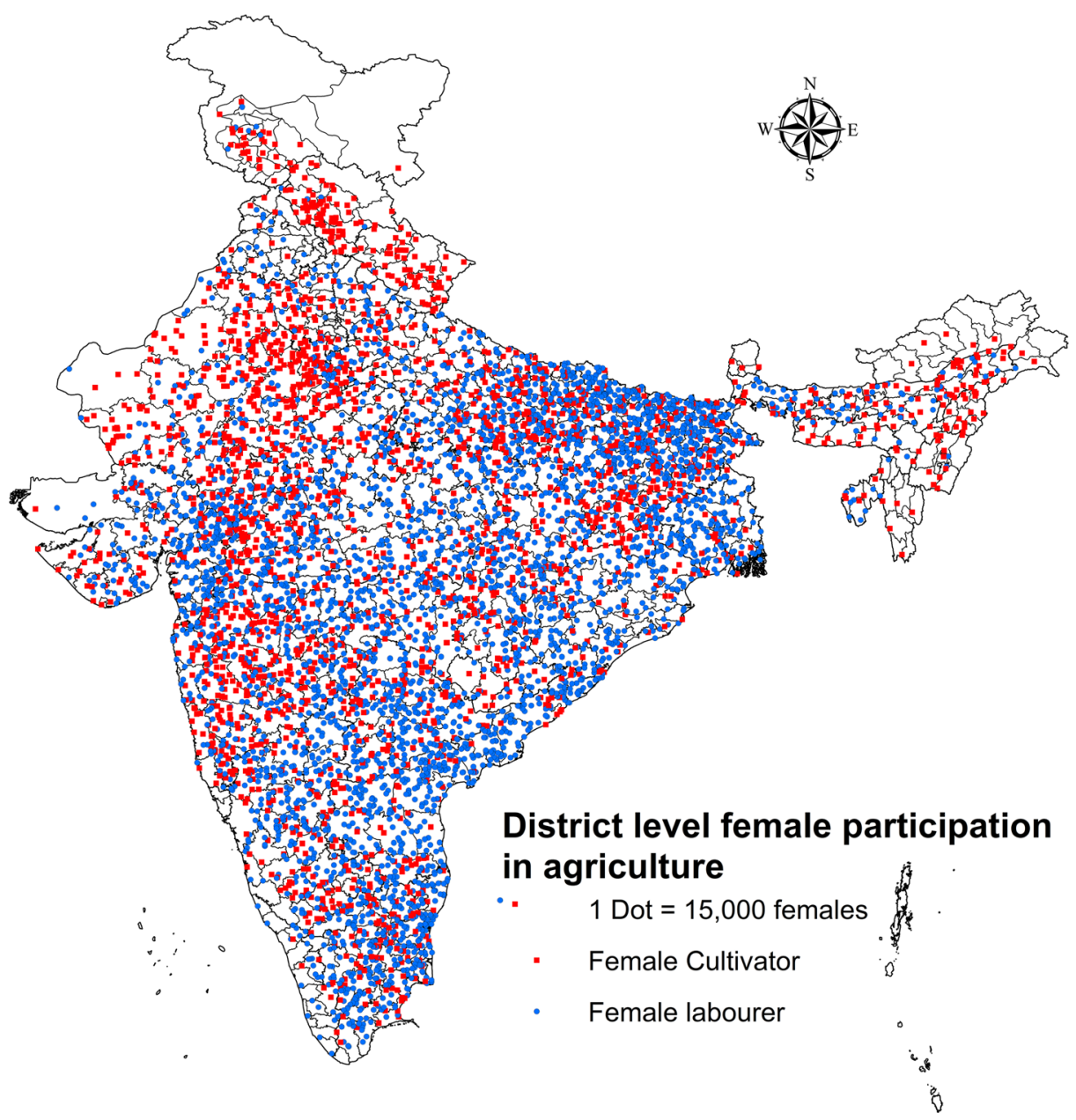

Fig. 1 District-level mapping of "female participation in agriculture" indicator, which comprises of female cultivators and laborers. The figure highlights the absolute numbers of female cultivators and laborers for all the 641 districts in the country (Census of India 2011) 


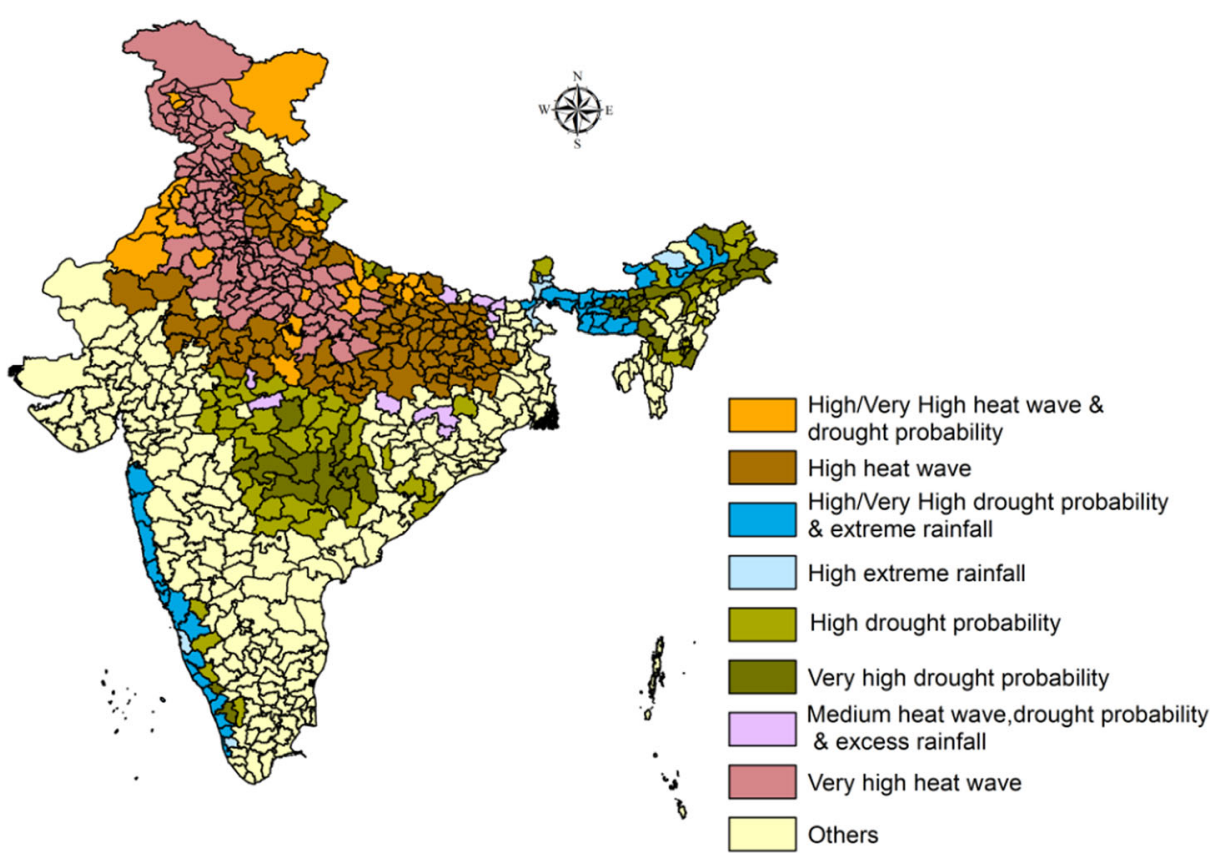

Fig. 2 District-level mapping of probability of drought, heat wave, and excess rainfall in India based on a standardized precipitation index (SPI) data from 1981 to 2011 (drought probability) and b data from the Indian Meteorological Department from 1981 to 2011

of North West India. These regions face an average of 33\% probability of drought, while the other parts of the country experience an average of $14 \%$ drought probability.

Districts exposed to "High" and "Very High" extreme rainfall, lying along the west coast and parts of the northeastern region of the country, experience an average of 13 days of excess rainfall, compared to only three in other regions. Some of these regions are also exposed to high probability of drought. As a result of high variability in precipitation, these regions become extremely vulnerable from a climate risk perspective. Similar is the case for districts in the northern parts of the country that are exposed to both high probabilities of drought as well as hotter days.

The results of the overlay analysis highlight 36 hotspot districts across ten states spread across the northern and central parts of the country (Fig. 3). ${ }^{4}$ These districts comprise of a total of 13.6 million women farmers, $57.4 \%$ of whom work as laborers. While the presence of these laborers is mostly in the eastern and central parts of the country, their numbers are exceeded by cultivators in the semi-arid region of Rajasthan. The proportion of women farmers in these hotspots, however, represents only $14.4 \%$ of the total females involved in agriculture in the country. The hotspots also include regions where the population is affected by two types of climate risks, suggesting the need to build higher adaptive capacity of the vulnerable population to help them cope with double exposure.

\subsection{Socioeconomic profiling of hotspots}

As a next step to prioritization, this study attempts to highlight the various challenges faced by women cultivators and laborers, belonging to the general as well as the

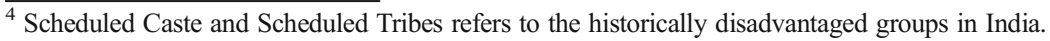




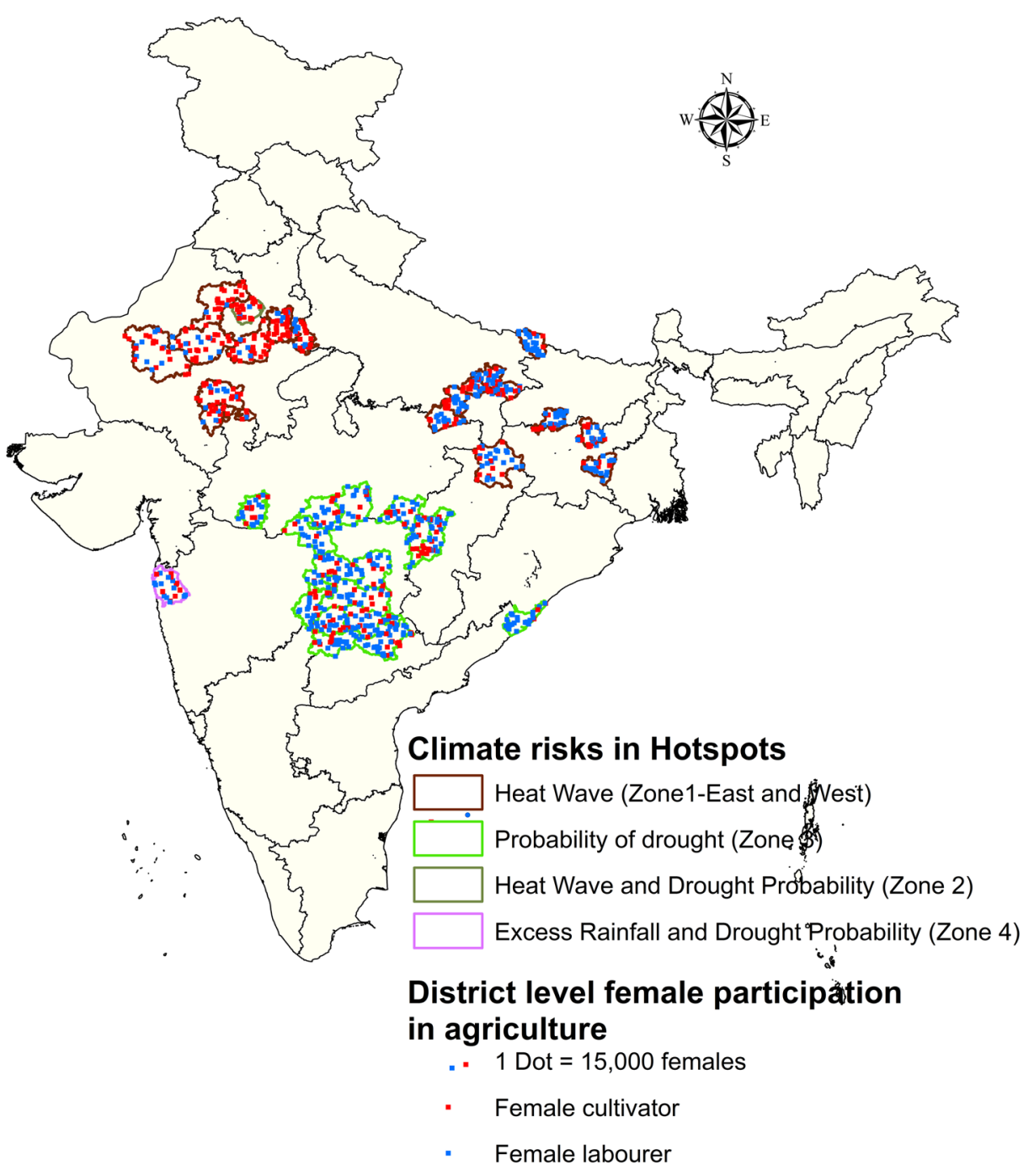

Fig. 3 Gender and climate risk hotspot districts in India. "Female participation in agriculture" was overlayed with each of the climate risks. Districts falling under the "High" and "Very High" categories of each of the layers were identified as hotspots (The hotspots have been divided into 4 separate zones based on the climatic risks faced by them. Given the wide geographic spread of Zone 1, it has been further divided into two sub-zones, east and west)

scheduled groups (Schedules Castes and Schedules Tribes) in the hotspots. Depending upon the local constraints and category of women farmers, the potential role of CSA technologies and practices in moderating the constraints is presented. Table 3 summarizes the below findings for the socioeconomic groups within these zones based on literature cited.

Female cultivators belonging to the general class in zone 1 west and zone 2 comprise the majority of the target population in these hotspots. They are primarily involved in sowing, weeding, watering, harvesting, and postharvesting of crops in their lands. Agriculture in the 
Table 3 Constraints faced by women cultivators and laborers, belonging to different social classes, in the hotspot zones. CSA technologies to reduce the constraints of female cultivators and laborers are also suggested

\begin{tabular}{|c|c|c|c|c|c|c|c|c|c|c|c|c|}
\hline \multirow{3}{*}{ 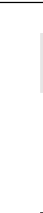 } & & Zone & - West & Zone & - East & & e 2 & & $e 3$ & & e 4 & \multirow{4}{*}{$\begin{array}{c}\text { Suggest } \\
\text { ed CSA } \\
\text { technolo } \\
\text { gies and } \\
\text { practice } \\
\quad s\end{array}$} \\
\hline & $\underset{a}{\text { Poverty }}$ & \multicolumn{2}{|c|}{$27 \%$} & \multicolumn{2}{|c|}{$45 \%$} & \multicolumn{2}{|c|}{$14 \%$} & \multicolumn{2}{|c|}{$40 \%$} & \multicolumn{2}{|c|}{$20 \%$} & \\
\hline & $\begin{array}{c}\text { Populat } \\
\text { ion } \\
\text { categor } \\
y^{b}\end{array}$ & $\begin{array}{l}\text { Gen } \\
\text { eral }\end{array}$ & $\begin{array}{l}\text { Sched } \\
\text { uled } \\
\text { group } \\
\text { s }\end{array}$ & $\begin{array}{l}\text { Gen } \\
\text { eral }\end{array}$ & $\begin{array}{l}\text { Sched } \\
\text { uled } \\
\text { group } \\
\text { s }\end{array}$ & $\begin{array}{l}\text { Gen } \\
\text { eral }\end{array}$ & $\begin{array}{c}\text { Sched } \\
\text { uled } \\
\text { group } \\
\text { s }\end{array}$ & $\begin{array}{l}\text { Gen } \\
\text { eral }\end{array}$ & $\begin{array}{l}\text { Sched } \\
\text { uled } \\
\text { group } \\
\text { s }\end{array}$ & $\begin{array}{l}\text { Gen } \\
\text { eral }\end{array}$ & $\begin{array}{c}\text { Sched } \\
\text { uled } \\
\text { group } \\
\text { s } \\
\end{array}$ & \\
\hline & $\begin{array}{c}\% \text { of } \\
\text { female } \\
\text { cultivat } \\
\text { ors }\end{array}$ & $59 \%$ & $16 \%$ & $26 \%$ & $8 \%$ & $78 \%$ & $13 \%$ & $20 \%$ & $9 \%$ & $16 \%$ & $27 \%$ & \\
\hline 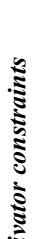 & $\begin{array}{l}\text { Limited } \\
\text { resourc } \\
\mathrm{e} \\
\text { access }\end{array}$ & & & & & & & & & & & $\begin{array}{c}\text { Livestoc } \\
\mathrm{k} \\
\text { Manage } \\
\text { ment, } \\
\text { Conting } \\
\text { ent Crop } \\
\text { Planning }\end{array}$ \\
\hline$\stackrel{\Xi}{\mathbf{\Xi}}$ & $\begin{array}{l}\text { Increas } \\
\text { ed } \\
\text { labour } \\
\text { hours } \\
\text { due to } \\
\text { male } \\
\text { outmigr } \\
\text { ation } \\
\text { Difficul } \\
\text { ty in } \\
\text { hiring } \\
\text { labour }\end{array}$ & & & & & & & & & & & $\begin{array}{c}\text { Labour } \\
\text { saving } \\
\text { practices } \\
\text { such as } \\
\text { Direct } \\
\text { Seeded } \\
\text { Rice and } \\
\text { System } \\
\text { of Rice } \\
\text { Intensifi } \\
\text { cation }\end{array}$ \\
\hline & $\begin{array}{c}\% \text { of } \\
\text { female } \\
\text { labour } \\
\text { ers } \\
\end{array}$ & $15 \%$ & $10 \%$ & $36 \%$ & $30 \%$ & $5 \%$ & $4 \%$ & $41 \%$ & $30 \%$ & $8 \%$ & $49 \%$ & \\
\hline 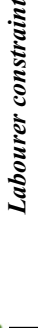 & $\begin{array}{l}\text { Lower } \\
\text { wage } \\
\text { income } \\
\text { /High } \\
\text { depend } \\
\text { ence on } \\
\text { wages } \\
\text { (in case } \\
\text { of male } \\
\text { migrati } \\
\text { on) }\end{array}$ & III & & II & & & & & & & & $\begin{array}{l}\text { ICT for } \\
\text { awarene } \\
\text { ss and } \\
\text { capacity } \\
\text { building, } \\
\text { Livestoc } \\
\text { k } \\
\text { manage } \\
\text { ment, } \\
\text { improve } \\
\text { d seeds, }\end{array}$ \\
\hline
\end{tabular}

Constraints faced by most of the women; Constraints faced by few women/data not available

${ }^{\text {a }}$ Poverty is represented by the district Head Count Ratio (Urban and rural combined) which has been taken from the study by Mohanty et al. (2016)

${ }^{b}$ The classification is as per the Census of India (Census of India 2011). Scheduled groups comprise of Scheduled Caste and Scheduled Tribe

region is increasingly becoming feminized as a result of male outmigration. This phenomenon is more prominent in the case of households belonging to scheduled groups with low levels of income and land holdings (UNDP 2014). However, lower literacy levels along with 
sociocultural norms associated with a patriarchal structure limit productivity of female cultivators by inhibiting decision-making and access to key resources including credit, information, and markets (Sharma et al. 2016; Torri 2010). In the context of heat wave and high drought probability, therefore, knowledge-smart CSA technologies, such as contingent crop planning and ICT-based agro-advisory services seem appropriate to help these women cultivators deal with income variability as well as information needs related to cultivation and harvesting practices, along with market knowledge. Similarly, practices related to livestock management, such as concentrate feeding and fodder management for livestock can prevent income losses from this source (Mittal 2016; Khatri-chhetri et al. 2017). On the other hand, given high dependence on low and variable wage income along with minimal asset endowments, low-cost interventions, such as heat tolerant seed varieties may be more relevant for female laborers in the region.

The eastern part of zone 1 is characterized by the majority presence of poor female agricultural laborers, of whom a substantial proportion belongs to the scheduled groups. Rice is one of the major crops in the region, and female laborers are involved in transplanting, weeding, and harvesting of the crop (Datta and Rustagi 2012). Laborers, like in other regions, are highly dependent on wage income from agriculture, which is lower for females, especially during times of climatic stresses (Mahajan 2012). Within the scheduled groups, male migration and low incomes create additional burden for the women left behind, further augmenting their farm labor work and domestic responsibilities (Ravera et al. 2016). Consequently, this may have negative effects on their health and nutrition status. Low cost and potentially profitable CSA practices, such as improved seed varieties and weather based agro-advisories may be considered as plausible options to help these female laborers reduce their dependency on wage income as well as improve their nutrition status. While improved seeds can help increase their own land production and income, by providing a marketable surplus, agro-advisories can further help reduce cost of production along with providing information related to nutrition and health (Nyasimi and Huyer 2017). Female cultivators within the general class are involved in supervision of labor, harvesting/postharvesting activities as well as animal husbandry. Women belonging to scheduled groups also undertake other farm activities, such as weeding, transplanting, and harvesting (Datta and Rustagi 2012). Limited access to agricultural tools and knowledge about new practices limits the scope of reducing time and labor efforts for female cultivators. This becomes a greater challenge in case of male migration in cultivator households, where women not only shoulder dual responsibilities of farm and household management, but also face difficulties in hiring labor (Paris et al. 2005; Bhatta et al. 2015; Singh et al. 2015). Thus, in the absence of wage laborers, labor-saving CSA technologies, complemented by ICT-based agro-advisories as well as livestock management practices can aid in drudgery reduction and lessening the gap of access to agricultural tools and knowledge for female cultivators in this region. However, this may negatively affect the wage employment opportunities of female laborers if these practices displace their labor requirement (Beuchelt and Lone 2013).

Female laborers and cultivators in zones 3 and 4 also face challenges related to income, wages, and access to labor, land, and institutions (Xenarios et al. 2017). Laborers form the majority of women in agriculture in this region as well. High probability of drought and extreme variation in rainfall pattern (especially in zone 4) directly impacts yields, by affecting the quantity and quality of farm inputs, such as water. In such a case, limited access to community-based water resources, credit facilities, information, and advisory services among other resources essential to cope with agricultural income loss, further worsen the coping 
capacity of female farmers in the region, especially poor and marginal laborers (Lambrou and Nelson 2010). Female cultivators spend a substantial time in recruiting and supervising laborers and in some regions often face labor shortage due to shifting of labor towards employment generation programs of the government that provide better remuneration compared to agricultural labor work (Xenarios et al. 2017). Labor-saving CSA technologies, such as direct-seeded rice and system of rice intensification can, therefore, be considered by these female cultivators to lessen their labor burden during the time of shortage. Water-smart CSA technologies such as water-harvesting, as well as weather-smart and knowledge-smart interventions, including weather based agro-advisory services, climate information, and livestock as a diversification strategy, can also serve as suitable interventions to help woman laborers, especially those with marginal landholdings, to deal with drought induced water-stresses, rainfall variations, lack of access to information, and alternative income sources during times of yield failures.

\subsection{Systematic literature review}

A systematic review of literature on gender and climate change in agriculture in India resulted in a list of 23 studies conducted in the last 10 years across multiple districts in India. While 21 of these studies have been conducted outside the hotspot districts (as seen by Fig. 4), the lessons from these studies can be used for addressing gender constraints in the hotspots. For instance, studies conducted in Bihar point to high vulnerability of poor, small, and marginal female cultivators, in households with migrant members, to drought and heat waves as a result of factors, such as lack of access to financial and agricultural resources and increased labou burden. Off-farm opportunities, exposure to training, and improving access to irrigation are suggested as some of the strategies to improve adaptive capacities of these female farmers. They also suggest promotion of access to schooling and participation in training and awareness to encourage adoption of practices, such as improved seeds, intercropping, and crop rotation for less educated female laborers belonging to scheduled groups. As pointed out by Mittal 2016, agro-information and weather services on mobile phone can be an important tool to empower women to adopt technologies and practices as per their needs. Similarly, studies in the northeastern states of India suggest community-based water initiatives, adoption of stress tolerant seed varieties (for flood), pest and disease management, livestock management, and site-specific training programs to enable women farmers cope with climatic risks of flood and heat waves. Literature from western parts of India, highlights the role of women's self-help groups (SHGs) as an effective channel to provide women access to agricultural inputs, credit, community participation, and market, especially for poor cultivators, in heat stressed conditions. Agroforestry for women laborers in tribal areas and non-agricultural activities, such as rope making have been promoted for income diversification of laborers through these SHGs. Studies in Andhra Pradesh and Tamil Nadu stress upon the establishment, training and promotion of women SHGs to implement various initiatives for adaptation to drought conditions, including livestock management, small-scale technologies related to soil moisture conservation, and capacity building for improved decision-making within household. Strengthening of local social networks has been identified as a means for improving adaptive capacity of female farmers especially laborers and scheduled groups across regions. The literature also suggests potential areas for future research in the concerned field, such as climate change impact in context of changing gender roles within the household as a result of male migration, intra-household decision-making, especially with respect to technology, and the gender responsiveness of current technology initiatives. 


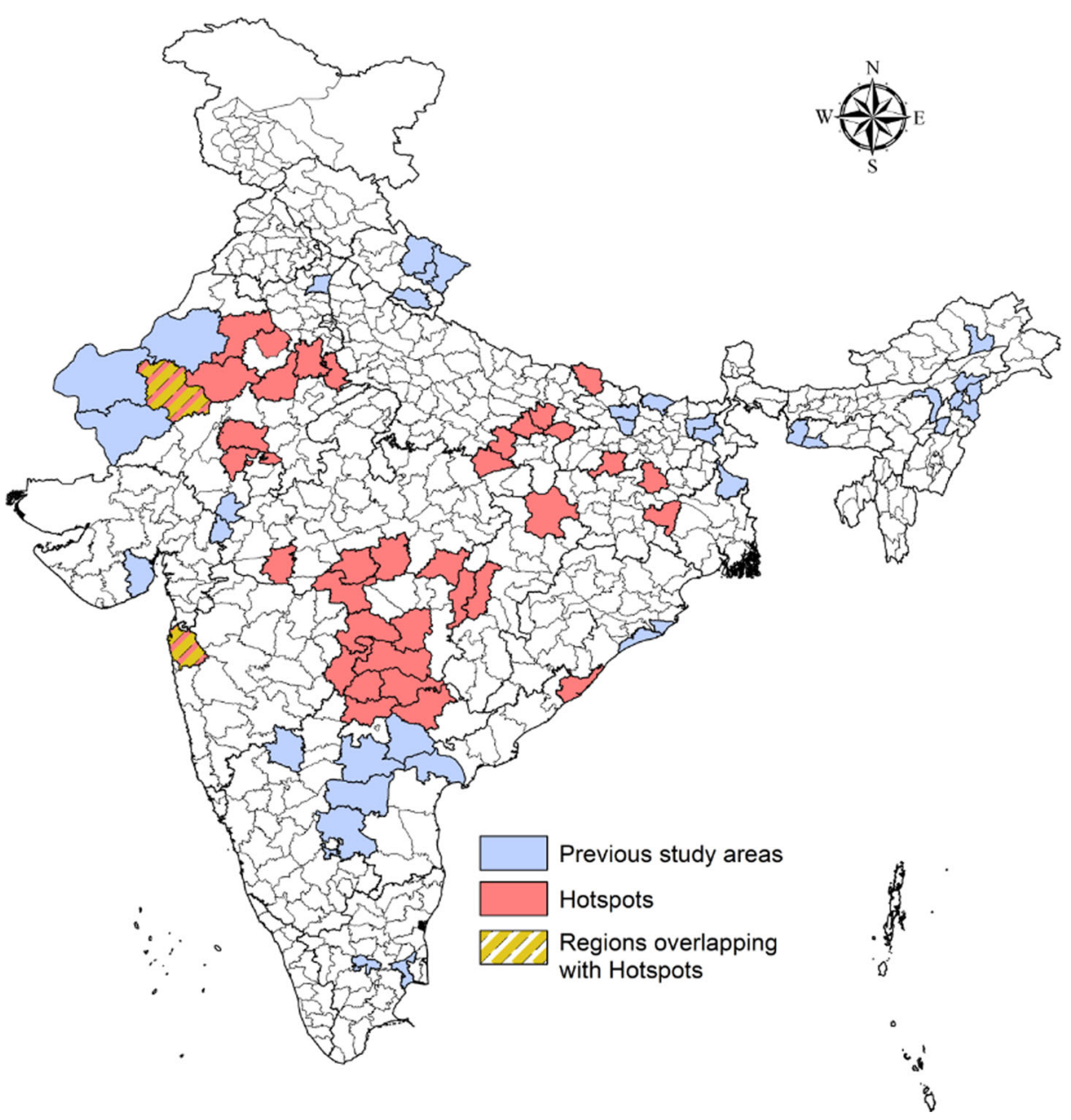

Fig. 4 Regional differences between hotspots and studies conducted in last 10 years. Districts where primary studies focusing on gender and climate change have been conducted, have been mapped along with the hotspots derived from this study

\section{Conclusion}

Expanding interest in climate change and gender relations, necessitates efficient channeling of resources for successful interventions in the fields. This study proposes a simple methodology to highlight broad geographical regions for such interventions. Though regional prioritization or "hotspot" mapping is relatively new in the field of gender, it presents interesting findings for future course of action. The study also suggests CSA options as a potential solution to assist the female farmers to adapt to the changing climate, while trying to address some of the constraints faced by them in agriculture. The adoption and effectiveness of these CSA options will depend on several socioeconomic factors and local conditions that need to be researched upon further in these hotspots.

Government level policy planning focuses on implementation of outcome oriented strategies mostly targeted to cover a large proportion of the target population. Results from this 
analysis can be therefore used as an input for planning gender-based policies to enable streamlining of priorities. This may be done by including special provisions as part of the women specific state or national level policies for these hotspot regions or by allocating resources for activities specially targeted at these hotspots. The hotspot identification needs to be followed by further examination of gender issues in each of the hotspots to formulate suitable adaptation options. In this context, assessment of the socioeconomic characteristics of the hotspot population can help in further reforming interventions. Thus, combining a topdown methodology with a bottom-up assessment of the issues involved can result in a comprehensive climate change adaptation planning for the vulnerable female farmers.

Acknowledgments Authors are thankful to Mr. Ponraj Arumugam for assisting with GIS mapping.

Funding information This work was implemented as part of the CGIAR Research Program on Climate Change, Agriculture and Food Security (CCAFS), which is carried out with support from CGIAR Fund Donors and through bilateral funding agreements. For details please visit https://ccafs.cgiar.org/donors. The views expressed in this document cannot be taken to reflect the official opinions of these organizations.

Open Access This article is distributed under the terms of the Creative Commons Attribution 4.0 International License (http://creativecommons.org/licenses/by/4.0/), which permits unrestricted use, distribution, and reproduction in any medium, provided you give appropriate credit to the original author(s) and the source, provide a link to the Creative Commons license, and indicate if changes were made.

\section{References}

Bernier, Q et al. (2015) Gender and institutional aspects of climate-smart agricultural practices: evidence from Kenya. CCAFS Working Paper No. 79. CGIAR Research Program on Climate Change, Agriculture and Food Security (CCAFS). Copenhagen, Denmark. Available online at: https://cgspace.cgiar. org/rest/bitstreams/53043/retrieve

Beuchelt TD, Lone B (2013) Gender, nutrition- and climate-smart food production: opportunities and trade-offs. Food Security 5(5):709-721. https://doi.org/10.1007/s12571-013-0290-8

Bhatta GD, Aggarwal PK, Poudel S, Belgrave DA (2015) Climate-induced migration in South Asia: migration decisions and the gender dimensions of adverse climatic events. J Rural Community Dev 10(4):1-23

Census of India (2011) Population Enumeration Data (Final Population) Office of the Registrar General and Census Commissioner, Ministry of Home Affairs, New Delhi, India http://www.censusindia.gov.in.

Datta A, and Rustagi P (2012) Status of Women in Bihar: Exploring Transformation in Work and Gender Relations.Institute for Human Development, New Delhi India http://www.ihdindia.org/rpb/pdf/Datta-andRustagi-2012.pdf accessed 24th July 2017

Demetriades J, Esplen E (2008) The gender dimensions of poverty and climate change adaptation. IDS Bull 39(4):24-31. https://doi.org/10.1111/j.1759-5436.2008.tb00473.x

Ericksen P, Thornton P K, Notenbaert A M O et al. (2011) Mapping hotspots of climate change and food insecurity in the global tropics. CCAFS Report No. 5. https:/ccafs.cgiar.org/publications/mapping-hotspotsclimate-change-and-food-insecurity-global-tropics\#.WZQZUzMjGUk. Accessed 24th July 2017

Fisher M, Carr ER (2015) The influence of gendered roles and responsibilities on the adoption of technologies that mitigate drought risk: the case of drought-tolerant maize seed in eastern Uganda. Glob Environ Chang 35:82-92. https://doi.org/10.1016/j.gloenvcha.2015.08.009

Goh A H (2012) A literature review of the gender-differentiated impacts of climate change on women's and men's assets and well-being in developing countries. International Food Policy Research Institute, CAPRi Work. https://doi.org/10.2499/CAPRiWP106. Accessed 20th July 2017

Habtezion S (2013) Overview of linkages between gender and climate change, Policy Brief, United Nations Development Programme, New York. http://www.undp.org/content/dam/undp/library/gender/Gender\%20 and\%20Environment/TM1_AsiaPacific_Capacity.pdf. Accessed 24 July 2017

International Labour Organization (2016) Women at Work: Trends 2016. ILO Geneva. http://www.ilo. org/wcmsp5/groups/public/_dgreports/_dcomm/_publ/documents/publication/wcms_457317.pdf. Accessed 24th July 2017 
Jost C, Kyazze F, Naab J et al (2015) Understanding gender dimensions of agriculture and climate change in smallholder farming communities. Clim Dev 8(2):133-144. https://doi.org/10.1080 $/ 17565529.2015 .1050978$

Khan T, Kishore A, Joshi PK (2016) Gender dimensions on farmers 'preferences for direct-seeded rice with drum seeder in India. International Food Policy Research Institute, New Delhi http://www.ifpri. org/publication/gender-dimensions-farmers \%E2\%80\%99-preferences-direct-seeded-rice-drum-seeder-india, Accessed 25th June 2017

Khatri-chhetri A, Aggarwal PK, Joshi PK, Vyas S (2017) Farmers' prioritization of climate-smart agriculture ( CSA ) technologies. Agric Syst 151(2017):184-191. https://doi.org/10.1016/j.agsy.2016.10.005

Kristjanson P, Bryan E, Bernier Q et al. (2017) Addressing gender in agricultural research for development in the face of a changing climate: where are we and where should we be going? Int J Agric Sustain 1-19. https://doi.org/10.1080/14735903.2017.1336411

Lambrou Y and Nelson S (2010) Farmers in a changing climate: does gender matter?: Food Security in andhra Pradesh, India. Food and Agriculture Organization of the United Nations Rome http://www.fao. org/docrep/013/i1721e/i1721e01.pdf. Accessed 20th July 2017

Lipper L, Thornton P, Campbell BM et al (2014) Climate-smart agriculture for food security. Nat Clim Chang 4: 1068-1072. https://doi.org/10.1038/nclimate2437

Mahajan, K (2012) Rainfall shocks and gender wage gap: agricultural labor in India. In 8th Annual Conference on Economic Growth and Development http://www.isid.ac.in/ pu/conference/dec_12_ conf/Papers/KanikaMahajan.pdf. Accessed 20th July 2017

Mehar M, Mittal S, Prasad N (2016) Farmers coping strategies for climate shock: is it differentiated by gender? J Rural Stud 44(April):123-131. https://doi.org/10.1016/j.jrurstud.2016.01.001

Mersha AA, Van Laerhoven F (2016) A gender approach to understanding the differentiated impact of barriers to adaptation: responses to climate change in rural. Reg Environ Chang 16(6):1701-1713. https://doi. org/10.1007/s10113-015-0921-z.

Mittal S (2016) Role of mobile phone-enabled climate information services in gender-inclusive agriculture. Gend Technol Dev 20(2):200-217. https://doi.org/10.1177/0971852416639772

Mnimbo TS, Mbwambo J, Kahimba FC, Tumbo SD (2016) A gendered analysis of perception and vulnerability to climate change among smallholder farmers: the case of same district, Tanzania. Climate and Development 8(1):95-104. https://doi.org/10.1080/17565529.2015.1005038

Mohanty SK, Govil D, Chauhan RK, Kim R, Subramanian SV (2016) Estimates of poverty and inequality in the districts of India, 2011-2012. J Dev Policy Pract 1(2):142-202. https://doi.org/10.1177/2455133316642338.

Murage A (2015) Gender specific perceptions and adoption of the climate-smart push-pull technology in eastern Africa. Crop Prot 76:83-91. https://doi.org/10.1016/j.cropro.2015.06.014

Nyasimi M, Huyer S (2017) Closing the gender gap in agriculture under climate change. Agric Dev 30:37-40

o'Brien K, Leichenko R, Kelkar U et al (2004) Mapping vulnerability to multiple stressors: climate change and globalization in India mapping vulnerability to multiple stressors : climate change and globalization in India. Glob Environ Chang 14(4):303-313. https://doi.org/10.1016/j.gloenvcha.2004.01.001

Paris T, Singh A, Luis J, Hossain M (2005) Labour outmigration, livelihood of rice farming households and women left behind: a case study in Eastern Uttar Pradesh. Econ Polit Wkly 40(25):2522-2529

Pérez C, Jones EM, Kristjanson P et al (2015) How resilient are farming households and communities to a changing climate in Africa? A gender-based perspective. Glob Environ Chang 34:95-107. https://doi. org/10.1016/j.gloenvcha.2015.06.003

Rao BB, Chowdary PS, Sandeep VM et al (2015) Spatial analysis of the sensitivity of wheat yields to temperature in India. Agric For Meteorol 200:192-202. https://doi.org/10.1016/j.agrformet.2014.09.023

Ravera F, Martín-López B, Pascual U, Drucker A (2016) The diversity of gendered adaptation strategies to climate change of Indian farmers: a feminist intersectional approach. Ambio 45(3):335-351. https://doi. org/10.1007/s13280-016-0833-2

Ray-Bennett NS (2009) The influence of caste, class and gender in surviving multiple disasters: a case study from Orissa, India. Environ Hazards 8(1):5-22. https://doi.org/10.3763/ehaz.2009.0001

Sharma N, Kumar S, Ravula P, Tyagi P (2016) Mainstreaming Gender and Empowering Women in Agriculture in the Thar Region of India. Research Report 68. Technical Report. ICRISAT, Telangana, India. http://oar. icrisat.org/9823/. Accessed 24 July 2017

Singh KM, Singh RKP, Kumar A, Bharati RC (2015) Male Worker Migration and Women Empowerment: a case of Bihar, India. J AgriSearch 2(3):200-205. https://doi.org/10.13140/RG.2.1.1353.1365

Singh K, McClean CJ, Büker P, Hartley SE, Hill JK (2017) Mapping regional risks from climate change for rainfed rice cultivation in India. Agric Syst 156:76-84. https://doi.org/10.1016/j.agsy.2017.05.009

Srivastava N, Srivastava R (2017) Women, work, and employment outcomes in rural India. Econ Polit Wkly 45(28):49-63

Subathra C (2015) Scenario of cultivators and agricultural laborers — a study. Int J Res 2(10):1133-1139 
Sugden F, Clement F (2014) Agrarian stress and climate change in the Eastern Gangetic Plains: gendered vulnerability in a stratified social formation. Glob Environ Chang 29:258-269. https://doi.org/10.1016/j. gloenvcha.2014.10.008

Thornton PK, Jones PG, Owiyo T et al (2008) Climate change and poverty in Africa: mapping hotspots of vulnerability. African J Agric Resour Econ 2(1):24-44

Torri MC (2010) Power, structure, gender relations and community-based conservation: the Cawswe Study of the Sariska Region, Rajasthan India. J Int Womens Stud 11(4):1-18

UNDP (2014) Aajeevika - livelihoods in Rajasthan: status, constraints and strategies for sustainable change. Discussion paper series - 6. Association for rural advancement through voluntary action and local involvement. http://www.in.undp.org/content/india/en/home/library/hdr/human-development-discussionpapers/aajeevika_livelihoods-in-rajasthan — status-constraints-and-s.html. Accessed 24 July 2017

World Bank Group, FAO, IFAD (2015) Gender in climate-smart agriculture: module 18 for gender in agriculture sourcebook. World Bank, Food and Agriculture Organization of the United Nations, and the International Fund for Agricultural Development. https://openknowledge.worldbank.org/handle/10986/22983. Accessed 24 July 2017

Xenarios S, Kakumanu KR, Nagothu US, Kotapati GR (2017) Gender differentiated impacts from weather extremes: insight from rural communities in South India. Environ Dev. https://doi.org/10.1016/j. envdev.2017.05.002 